\title{
Water Quality Sampling in Billy Barquedier National Park and Surrounding Areas, Belize, C.A.
}

\author{
Taylor Boatwright" ${ }^{1}$ Briana Monarca ${ }^{1}$, Minerva Brauss ${ }^{1 \#}$, K. Daniel Brauss ${ }^{1 \#}$ \\ ${ }^{1}$ Frances Marion University, Florence, SC, USA \\ \#Advisor
}

\section{$\underline{\text { ABSTRACT }}$}

Water quality is an issue that can require intervention in order to protect the health of individuals. In particular, many communities in rural areas of Belize, Central America lack potable drinking water. In order to address remediation tactics for communities surrounding the Billy Barquedier National Park, we collected and tested water samples from the source in the park and the household sites in the Valley community in the Stann Creek District, Belize, C.A. We are interested in determining the source of contamination as well as correlations between microbial populations E. coli and chemical (or physical) components like nitrate levels. Testing involved taking samples as well as testing in the field with the Pro DSS water quality meter. Lab testing used a colorimeter and autoclave to test the microbial and chemical makeup. We discuss the results, their implications, and future work.

\section{Introduction}

Access to potable water is something that citizens in first-world countries do not often think about as an issue in their everyday lives. However, this is unfortunately not the case in other countries, such as in the rural areas of Belize. In this study, we collected water samples from 6 different sites in the Billy Barquedier National Park and from 3 houses in the Valley Community. We wanted to see the variability of water samples from the top versus the bottom of the mountain (the water that the citizens were accessing). We recorded physical, chemical, and microbial parameters.

Water quality standards are widely accepted for the levels of chemical and bacterial components, and each of these values can indicate specific events that are taking place. Cabral (2010) says, "The presence of total coliform gram-negative or fecal coliforms can be used to indicate fecal contamination, but are not the preferred choice by professionals" (Cabral, 2010). Since there are so many other bacteria strains that fall into these categories, we have to look at other, more specific factors, such as E. coli which Cabral (2010) states is the only true indicator of fecal contamination in a water source. Other biological variables, such as coliform, can indicate the presence of potential pathogens, but not specific information regarding the type, only the effects it may cause such as gastrointestinal problems. One of the main sources of E. coli contamination is by runoff of rain or water systems where animal matter can easily become a source of contamination. This is especially evident in areas with large wildlife populations, domestic or wild. Our study began by looking at the source of contamination. We hypothesized that if the contamination took place within the forest, then the levels of bacteria would be higher at those sites.

In Belize, the primary source of water is through the Belize Water Service (BWS) or Village water board (VWBs). The latter is focused on rural areas of the country and is set up as a local governing system. They found that in the VWBs, only $38 \%$ are actively chlorinating water and only $36 \%$ have meters on the systems (Grau et. al, 2013). The lack of maintained systems and working systems is a primary factor in the lack of water cleanliness caused 
largely by a lack of financial resources. None of these systems have filtration systems or management for sewage. Home-made wells are a common source of water for citizens that do not have adequate access to the VWB systems. Husaini et al. (2020) explain that the VWB systems typically are filled with rainwater runoff or wells, which is found to be a potential contamination factor for E. coli bacteria. Many of the systems also rely on in-home sanitation and management that is not always properly communicated or efficient enough to rid of all contamination. The water they receive through this means should only be used for cleaning and cooking purposes, but that is ignored at times. For the particular villages that we collected samples from, the residents have pipe systems that are run directly from the nearby creeks and streams. This system has no chlorination and works by using varying PVC pipe sizes to create pressure along with gravity to move the water to the homes. The water stemming from these pipes is only supposed to be used for bathing or cooking. Improper consumption of the water is known to be harmful, but most of these warnings are ignored or missed.

The area we collected samples from is often used as farmland or for agricultural purposes. Because of this, we knew that nitrate levels would be higher due to fertilizers and animal waste. This means that the physical and chemical parameters should positively correlate with bacterial and microbial levels (i.e. higher E. coli and coliform bacteria). There are multiple strains of E. coli that can cause intestinal diseases and there are three types that can be transmitted through contaminated water: enterotoxigenic, enterohemorrhagic, and enteroinvasive serotypes. Each strand affects individuals differently through the symptoms they experience and it affects different populations depending on age and place of origin (Grau et. al, 2013). E. coli contamination occurs through improper sanitation of water, milk, or meat products. The more common strain, Enterotoxigenic E. coli (ETEC), most commonly affects children and travelers and Grau et. al. (2013) says it can "account for several hundred million cases of diarrhea and several tens of thousands of deaths each year". Based on the literature, we were examining the correlation between chemical and physical parameters in comparison to the bacteria levels. If the contamination was taking place from the water sources, then there should be a strong correlation between bacteria and nitrate levels.

\section{Acronyms and Definitions}

Chloride (Cl2)

Conductivity

Fecal Coliforms

Iron $(\mathrm{Fe})$

Nitrates (NO3-)
Naturally occurring anion that is found in all-natural water bodies. High levels do not indicate pollution but act as secondary indicators of other types of contamination. Non-toxic to humans but makes water unpotable because of the taste. Measured in $\mathrm{mg} / \mathrm{L}$.

The measure of the ability of water to pass an electrical current. Affected by inorganic dissolved solids (chloride, sulfate, sodium, calcium). Measured in $\mathrm{ms} / \mathrm{cm}$.

Bacteria that come from human and animal waste that indicates that the water supply may be vulnerable to contamination. It can be from improperly treated water, storm water runoff, or domestic animals or wildlife. Measured in CFU/ml.

Promotes bacterial growth and increased levels give water a reddish-brown discoloration. Can also give it a foul taste and odor. Measured in $\mathrm{mg} / \mathrm{L}$.

A nutrient necessary for all growth; however, high levels increase algae growth and can be toxic to humans resulting in illness and even death in infants. Sources of 


\section{Journal of Student Research}

Phosphates (PO3-)

Turbidity

University of Belize (UB)

Village Water Board

(VWB) nitrates may include human/animal waste, industrial pollutants, and runoff from heavily fertilized croplands and lawns. Measured in mg/L.

A form of phosphorus that is common in agricultural fertilizers, manure, and organic wastes in sewage and industrial effluent. This does not necessarily threaten human health; however, higher levels can increase algae growth and affect water treatment by causing low levels of oxygen. Measured in $\mathrm{mg} / \mathrm{L}$.

The measure of the clarity of a water body. Indicates water quality and filtration effectiveness. Causes of high turbidity can include soil erosion, wastewater discharges, runoff, farming practices, and excessive algae growth. Measured in Formazin Attenuation Units (FAU).

The University of Belize which research was done in conjunction with through their Biology and Statistics Departments.

Entities that provide water services in rural Belize. Responsible for overseeing the day-to-day management and operation of rudimentary water systems.

\section{Literature Review}

\section{Baseline Values}

To know what we should compare our collected values to, we looked at the drinking water regulations provided by the United States Environmental Protection Agency (EPA) and Centers for Disease Control and Prevention (CDC). We found that up to 4 milligrams per liter of chlorine were safe for drinking water and that this amount was unlikely to pose any threat to human health (Centers for Disease Control and Prevention [CDC], 2020). It was also found that 0 colony-forming units per milliliter were safe for human consumption for both total coliforms and E.Coli (Facts on Drinking Water, n.d.). Higher levels of either can result in gastrointestinal side effects or more severe cases in infants, elders, and those with compromised immune systems. In rare and extreme cases, these colony-forming units could cause fatal infections in the lungs, eyes, nervous system, or kidneys (Facts on Drinking Water, n.d.). Nitrates are also found to be common in rural areas due to agricultural purposes and can be harmful to humans (Husaini et al., 2020). Safe levels of nitrate (measured as nitrogen) are no more than 10 milligrams per liter (Environmental Protection Agency [EPA], 2021). Infants are more susceptible to the harmful effects that high levels of nitrates have, like shortness of breath (EPA, 2021). Iron levels provide significant information regarding the vulnerability of a water supply to contamination. High levels of iron can give drinking water a metallic taste and while this may not pose a threat to human health, these are slight secondary or aesthetic standards that are recommended but not enforced (EPA, 2020). The United States EPA suggests that no more than 0.3 milligrams per liter of iron should be found in drinking water (EPA, 2020). Lastly, we needed to find a baseline value for phosphates in drinking water. Water Technology (2012) states that "No more than $0.1 \mathrm{mg} / \mathrm{L}$ for streams that do not empty into reservoirs; no more than $0.05 \mathrm{mg} / \mathrm{L}$ for streams discharging into reservoirs; and no more than $0.024 \mathrm{mg} / \mathrm{L}$ for reservoirs" (Water Technology, 2012). However, the Food and Drug Administration (FDA) has recognized phosphates (at reasonable levels) as safe for humans to ingest (Water Technology, 2012). 


\section{Journal of Student Research}

\section{Similar Testing Methods}

Getachew et al. (2018), along with many others, also kept their samples in sterilized sampling bottles and at $4^{\circ} \mathrm{C}$ $\left(39.2^{\circ} \mathrm{F}\right)$ when collecting. Husaini et al. (2020) collected samples from reservoirs, wells, vats, and standpipes from 40 different villages using plastic bottles that were sterilized as well and rinsed with purified water. To better understand the variance of the water in rural areas of Belize, Husaini et al. (2020) traveled to collect samples from each district and tested each of the 40 samples twice. Before bottling the samples, it is important to let the faucets run to rid them of any buildup and/or contamination. For example, Adimalla (2021) ran the water for 15 minutes and rinsed the sampling bottles 5 times before any collecting of samples was performed. We followed similar collection and testing techniques.

\section{Methods}

\section{Location of Collections}

The geographical locations of the water sample collection sites were recorded in Table 1. This information was kept to give values on the specific portion of the mountain where the samples were obtained and their proximity to the household collection sites. It should be noted that there were rain showers throughout the day and temperatures had a low of $21.11^{\circ} \mathrm{C}\left(70^{\circ} \mathrm{F}\right)$ and a high of $32.22^{\circ} \mathrm{C}\left(90^{\circ} \mathrm{F}\right)$. We were collecting samples from 9:00 to 17:00 in the month of December, indicating we had varied weather patterns.

Table 1. Geographical information on the sites where collections were taken with descriptions of the sites or households.

\begin{tabular}{|l|l|l|l|l|}
\hline & Longitude & Latitude & Altitude & General Description \\
\hline Site 1 & -88.43176 & 17.019860 & 281.4 & First-order stream. \\
\hline Site 2 & -88.43169 & 17.019150 & 245.0 & Shallow stream, slow running. \\
\hline Site 3 & -88.43174 & 17.019100 & 241.9 & Rapid running water and pool, stones. \\
\hline Site 4 & -88.42430 & 17.001000 & 196.8 & Stream from the logging area. \\
\hline Site 5 & -88.43013 & 17.081600 & 229.1 & Narrow. Shallow water. \\
\hline Site 6 & -88.43707 & 17.009780 & 160.3 & $\begin{array}{l}\text { Wide, fast-flowing street stream, containing water } \\
\text { distributed to the community. Caption Area. }\end{array}$ \\
\hline House 1 & -88.42438 & 16.998950 & 65.15 & $\begin{array}{l}\text { Wooden house in Steadfast Village, located across from } \\
\text { STACA Office. }\end{array}$ \\
\hline House 2 & -88.42419 & 17.000070 & 70.65 & $\begin{array}{l}\text { Cement house on the left side of Hummingbird highway, } \\
\text { going to Dangriga direction. }\end{array}$ \\
\hline
\end{tabular}




\section{Journal of Student Research}

\begin{tabular}{|l|l|l|l|l|}
\hline House 3 & -88.43025 & 17.016944 & 97.8 & Cement Brown House, Steadfast Village. \\
\hline
\end{tabular}

Figure 3 shows the water collection sites in reference to one another. Site 6's sample was taken by a park ranger as the terrain was not fit to hike after heavy rainfall in that area. The image gives a better view of the distance between sites and the elevations that were taken. This corresponds to the data in Table 1 as a visual reference.

Sites 1-5 flow into site 6 . Site 1 and 3 are first-order streams with site 2 being their intersection. Sites 4 and 5 are second-order streams from the intersection. Finally, site 6 is when the river is formed from the streams and is the village capture area. The river grows to become $10 \mathrm{ft}$ deep and $12 \mathrm{ft}$ wide. From the capture area, the village uses a 6 inch PVC pipe to collect water and reduces pipes to half-inch wide near the households, which aids in creating pressure. The water flows directly to homes with no chemical treatment. Table 1 gives more information about the specific location and general descriptions of the areas.

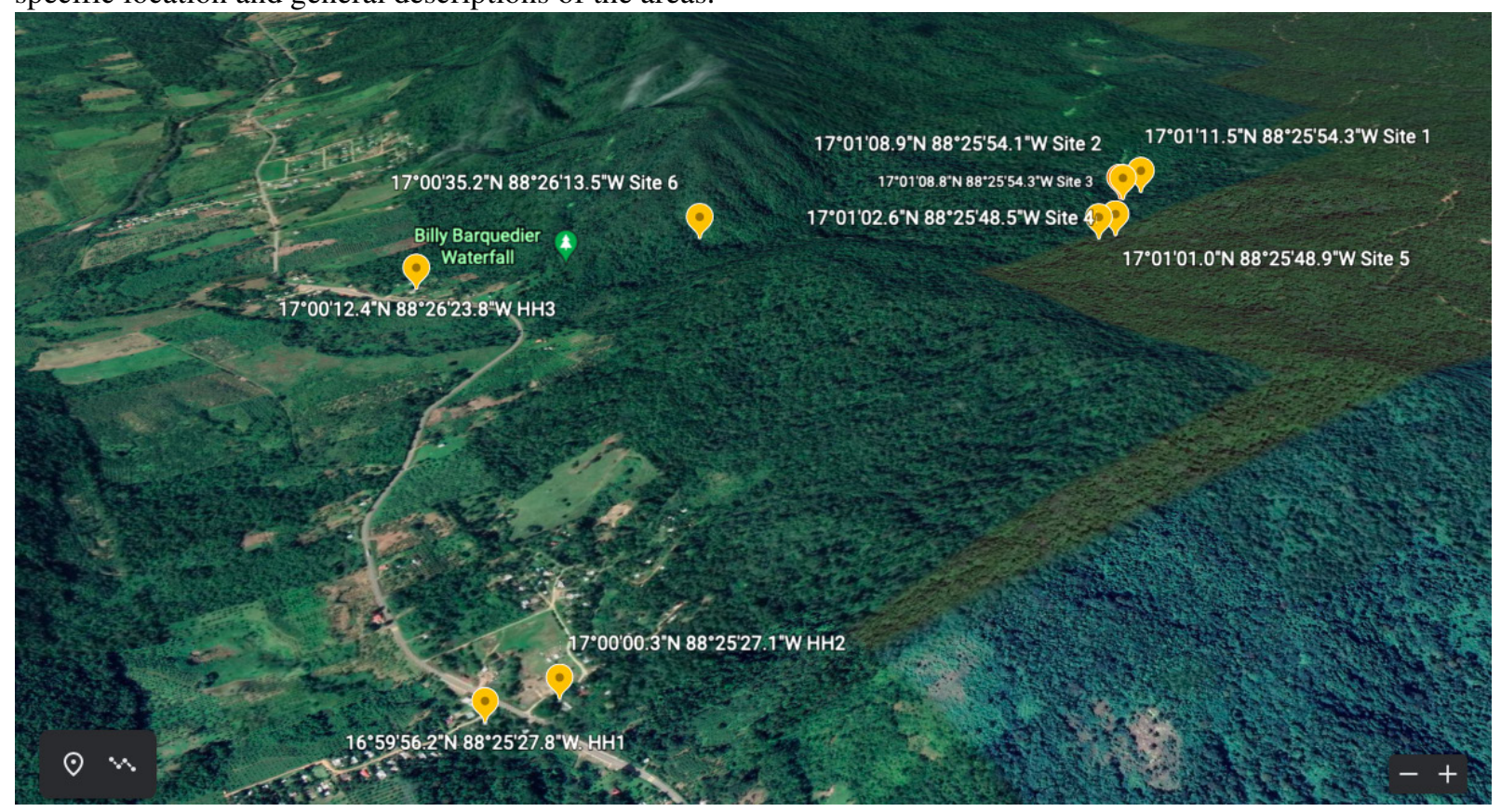

Figure 1. The water collection sites on a map view (Google, n.d.).

\section{Water Sample Collection}

6 Site Collection Process: To collect the water samples at the mountain sites, we used the Grab Sample Method. Clorox wipes were used on the bottle rim and cap before collection for cleansing. The bottle was submerged in the stream, against the current. We angled the bottle at $30^{\circ}$ and then at $90^{\circ}$ to eliminate the possibility of contamination and to rid the sampling bottles of air bubbles while filling. We then attached the lid while the sample bottle was still underwater. Two bottles were filled at each site, one for chemical analysis and one for microbial analysis, keeping them in a cooler with a regulated temperature of $4^{\circ} \mathrm{C}-6^{\circ} \mathrm{C}\left(39.2^{\circ} \mathrm{F}-42.8^{\circ} \mathrm{F}\right)$, which were then transferred to the UB Biology Laboratory. 
3 Household Collection Process: Sterilize the faucet and water bottle rim and cap using Clorox wipes. The faucet was turned on and water flowed for two minutes to rid sediments or impurities that may have been resting in the PVC pipes. The container was held for one minute under the running water and then the container was closed while still under the water. Similarly, two bottles were filled at each household.

\section{Measuring Physical Parameters}

A YSI 556 MPS - Multi-Probe will be used to determine the $\mathrm{pH}$, temperature, conductivity, and dissolved oxygen content on-site. The probe is to be submersed and remain at the top of the water column for two minutes after which the first reading was taken. A second reading was taken by placing the probe at the bottom of the water column for another two minutes. We ensured that before and after each reading, the probe was rinsed using distilled water. The average of the two readings was recorded. Turbidity is measured using the HACH DR 890 Colorimeter.

\section{Measuring Chemical Parameters}

The bottled samples were used for testing. A HACH DR 890 Colorimeter was used on-site to measure the concentration of Phosphate, Iron, and Chlorine. The low and high-range nitrates were tested at the UB Biology Laboratory.

\section{Measuring Biological Parameters}

Microbial testing must be done within 24 hours of water collection. Samples were diluted using the 10-fold dilution technique. Three samples of the stock are to be cultured on Mac Conkey Agar using the spread plate technique. After culturing, all the cultured samples are incubated at $0^{\circ} \mathrm{C}\left(32^{\circ} \mathrm{F}\right)$ in a Fisher brand Iso-Temp incubator for a period of 24 to 48 hours. Colonies are then counted and microbial concentrations are determined.

\section{Analyzing Data}

Three separate and independent samples were taken at each collection location for each parameter. The average of those values was calculated and used to represent that site's respective measure for each parameter. SPSS and Excel were used to organize and analyze the results that were obtained from the samples and lab testing.

\section{Correlation Equation used to create Correlation Matrix}

Due to the limited sample size of the study and the data not being normally distributed, we used the Spearman's Rank Order Correlation. The Spearman correlation was used to determine which physical or chemical parameters were highly correlated with bacterial parameters.

Equation 1: Spearmen's Rank Order Correlation (for no tied ranks):

$$
\rho=1-\frac{\sum_{i=1}^{9}\left(x_{i}-y_{i}\right)^{2}}{n\left(n^{2}-1\right)}
$$

where $\mathrm{i}$ is the ordered pair and $\mathrm{n}$ is the number of cases. The only requirements for this test are that there is a random sample with $\mathrm{n}$ pairs and each measurement pair is taken at the same time. This method was used because there is no requirement for the form of the distribution, unlike other methods such as Pearson. Pearson could not be used because the data did not fit the normality distribution requirement.

\section{Nonparametric Regression Line of Best Fit}




\section{Journal of Student Research}

After determining which physical or chemical parameters were highly correlated with the bacterial parameters, the Theil-Sen Nonparametric Regression Tests were used to present linear associations between the parameters. Equation [2] and [3] were used to present these associations.

Equation 2: Theil-Sen Nonparametric Regression Coefficient formula:

$$
S_{j i}=\frac{y_{j}-y_{i}}{x_{j}-x_{i}} \text { for } N=\left(\frac{n}{2}\right)
$$

where $\mathrm{i}$ and $\mathrm{j}$ represent which variable is being taken. Once all $S_{i j}$ are obtained, the median of all of the values will be chosen as $\hat{\beta}$. Next, solve for $\hat{\alpha}$ for each of the equations and find the median of the $\hat{\alpha}^{\prime} s$.

The chosen $\hat{\beta}$ and $\hat{\alpha}$ coefficients are used to write the slope-intercept equation for the nonparametric form.

Equation 3: Slope-Intercept Equation:

$$
y=\hat{\beta} x+\hat{\alpha}
$$

The Theil-Sen method was included because it does not assume linearity and does not allow outliers to affect the line of best fit. This equation was graphed onto a scatterplot for each of the compared values. The compared values were chosen based on their correlation coefficient in the correlation matrix.

\section{Results}

Our initial prediction was that if contamination was taking place in the forest, then the bacteria levels in the mountain collection sites would be higher than those in the households. Our findings suggest that the levels in the households were higher, but were not statistically significant due to small sample size in the households and sites. The mean for the households and sites for each physical, chemical, and microbial parameters are shown in Table 2.

Table 2. Descriptive statistics for the different parameters. The data is divided into the household average (HH), site average (S), and total average (Tot). There were three households and six sites, for a total of 9 collections in the total average. Chlorine samples were not taken at the sites.

\begin{tabular}{|l|c|c|c|c|c|c|c|c|c|}
\hline & \multicolumn{3}{|c|}{ Mean } & \multicolumn{3}{c|}{ Std. Deviation } & \multicolumn{3}{c|}{ Median } \\
\hline & HH & S. & Tot. & HH & S. & Tot & HH & S. & Tot. \\
\hline SPC (ms/cm) & 172.23 & 137.90 & 160.79 & 39.94 & 66.47 & 43.46 & 175.10 & 122.50 & 167.25 \\
\hline Conductivity (ms/cm) & 157.43 & 138.30 & 151.05 & 49.83 & 69.47 & 48.06 & 167.98 & 119.95 & 160.25 \\
\hline Turbidity (FAU) & 11.83 & 1.67 & 8.44 & 6.96 & 1.77 & 7.54 & 12.25 & 1.00 & 5.00 \\
\hline Temperature (C) & 22.98 & 24.97 & 23.64 & 0.63 & 0.74 & 1.22 & 23.00 & 24.95 & 23.00 \\
\hline Phosphate (mg/L) & 0.20 & 0.28 & 0.23 & 0.11 & 0.05 & 0.10 & 0.17 & 0.30 & 0.23 \\
\hline
\end{tabular}




\section{- Journal of Student Research}

\begin{tabular}{|l|c|c|c|c|c|c|c|c|c|}
\hline Nitrate High Range (mg/L) & 0.69 & 0.88 & 0.76 & 0.32 & 0.11 & 0.33 & 0.65 & 0.75 & 0.75 \\
\hline Chlorine (mg/L) & 0.01 & - & 0.01 & 0.01 & - & 0.01 & 0.02 & - & 0.02 \\
\hline Iron (mg/L) & 0.50 & 0.17 & 0.39 & 0.24 & 0.04 & 0.25 & 0.50 & 0.17 & 0.31 \\
\hline Chloride (mg/L) & 23.13 & 28.92 & 25.06 & 10.06 & 8.74 & 17.37 & 19.78 & 17.95 & 17.95 \\
\hline E. Coli (CFU/ml) & 26.17 & 21.00 & 24.44 & 26.98 & 14.14 & 23.40 & 20.00 & 20.00 & 20.00 \\
\hline Coliform Bacteria (CFU/ml) & 436.67 & 56.67 & 310.00 & 109.67 & 56.57 & 210.12 & 450.00 & 30.00 & 310.00 \\
\hline Gram (-) Bacteria (CFU/ml) & 205.33 & 43.33 & 151.33 & 138.11 & 49.50 & 137.44 & 215.00 & 20.00 & 120.00 \\
\hline
\end{tabular}

The values in table 2 were used to provide an overview of the data collected and propose a preliminary hypothesis for this project. Such comparisons with US EPA and other such organizations aided in gauging acceptable levels for potable drinking water. 

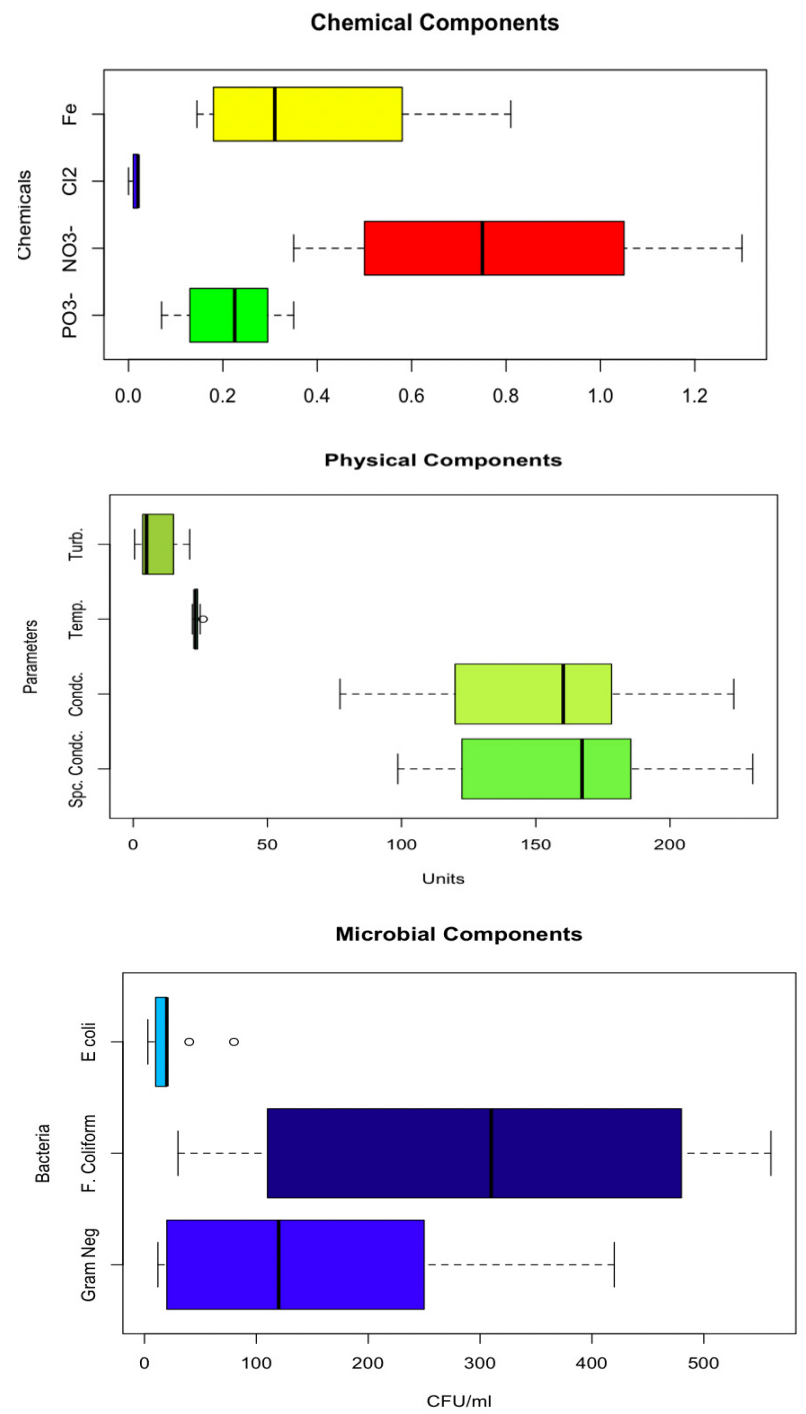

Figure 2. Box Plots for tested components.

Our second prediction was also proven incorrect as we saw no significant correlation between nitrates and bacteria levels. Instead, we saw significant correlation values between iron and both bacteria forms, turbidity and both bacteria forms, and iron and turbidity.

Table 3. Correlation Matrix created using Equation 1

\begin{tabular}{|l|l|l|l|l|l|}
\cline { 3 - 6 } \multicolumn{2}{l|}{} & Turbidity & Iron & Coliform Bacteria & Gram Bacteria \\
\hline \multirow{2}{*}{ Turbidity } & Correlation & 1.000 & $.979 * *$ & $.899 * *$ & $.793 *$ \\
\cline { 2 - 6 } & Sig. &. & .000 & .001 & .011 \\
\hline
\end{tabular}




\section{Journal of Student Research}

\begin{tabular}{|l|l|l|l|l|l|}
\hline \multirow{2}{*}{ Iron } & Correlation & $.979 * *$ & 1.000 & $.882 * *$ & $.782 *$ \\
\cline { 2 - 6 } & Sig. & .000 &. & .002 & .013 \\
\hline \multirow{2}{*}{ Coliform Bacteria } & Correlation & $.899 * *$ & $.882 * *$ & 1.000 & $.814 * *$ \\
\cline { 2 - 6 } & Sig. & .001 & .002 &. & .008 \\
\hline \multirow{2}{*}{ Gram Bacteria } & Correlation & $.793 *$ & $.782 *$ & $.814 * *$ & 1.000 \\
\cline { 2 - 6 } & Sig. & .011 & .013 & .008 &. \\
\hline
\end{tabular}

** correlation is significant at 0.01 level

* correlation is significant at 0.05 level

Turbidity v. Coliform Bacteria $y=29.509 x+115.139$

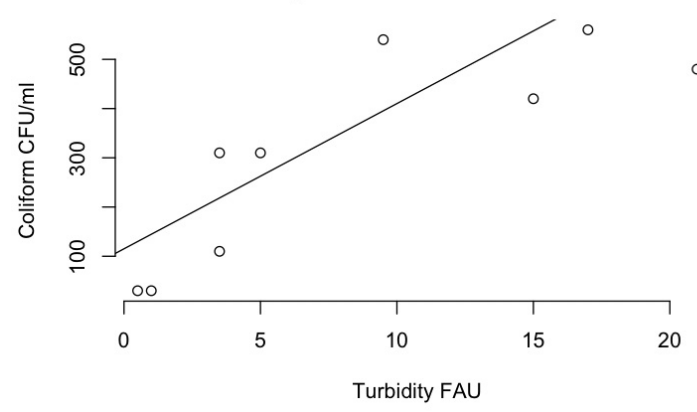

Turbidity v. Gram Negative Bacteria $y=17.143 x+11.527$

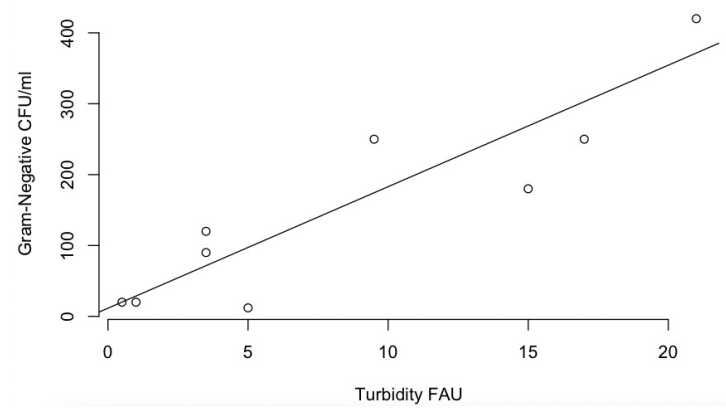

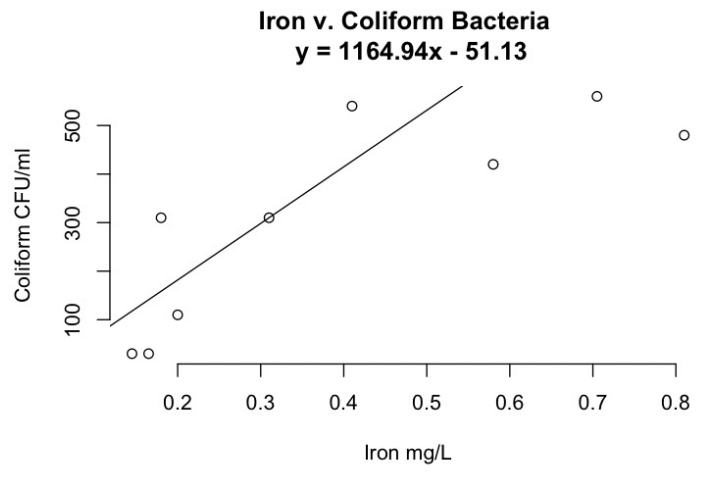

Iron v. Gram-Negative Bacteria $y=428.91 x-44.92$

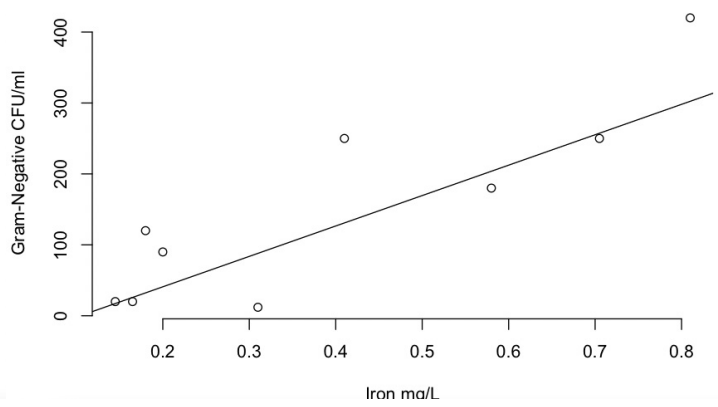

Iron v. Turbidity $y=30.4127 x-2.9692$

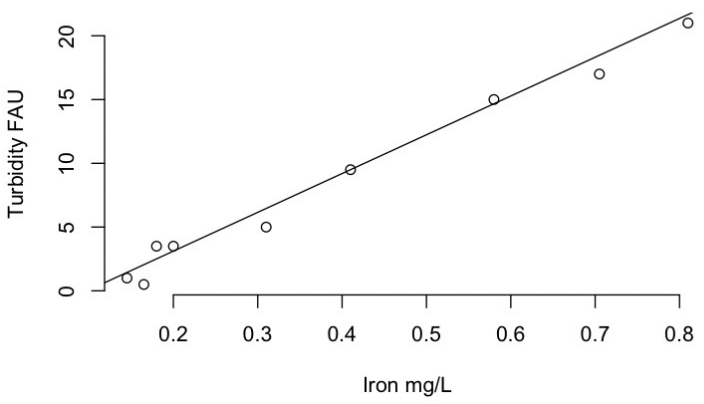


Figure 3. Nonparametric Regression lines with scatterplots using Equations 2 and 3.

\section{Discussion}

After looking over the basic statistics, we use the Spearmen correlation to centralize strong relationships. Table 2 shows the averages amongst the testing sites for all parameters and based on the prior literature, the majority of these values are significantly higher than the suggested amount to be considered safe for consumption. Table 3 began as a much larger table of all the correlations between all variables but was narrowed down to those with a strong or very strong correlation coefficient equal to or larger than 0.7. For each there is a very strong, positive monotonic relationship between the ranks of turbidity and iron $(\rho=0.979$ and $\mathrm{p}$-value $=0.000)$; turbidity and coliform bacteria ( $\rho=0.899$ and $\mathrm{p}$-value $=0.001)$; iron and coliform bacteria $(\rho=0.882$ and $\mathrm{p}$-value $=0.002)$; and coliform bacteria and gram-negative bacteria $(\rho=0.814$ and $\mathrm{p}$-value $=0.008)$. There is a strong, positive monotonic relationship for turbidity and gram-negative bacteria $(\rho=0.793$ and p-value $=0.011)$ and iron and gram-negative bacteria $(\rho=0.782$ and $\mathrm{p}$-value $=0.013$ ). We can see here that our initial hypothesis was incorrect as there is no significant correlation between nitrates and bacteria levels. We instead found statistically significant correlations between iron and bacteria as well as turbidity and bacteria levels. Therefore, further testing is needed to identify the cause and effect for these relationships.

Table 2 shows that on average, there were higher levels of bacteria in the households when compared to the mountain collection sites. The data was not normality distributed and the number of samples taken at the household sights and the mountain sights were small. Therefore, statistical significance was not tested. While we do not have significance levels due to the lack of data that was able to be taken during the time period, we can conclude for now that our initial hypothesis was incorrect. Contamination could be taking place closer to the bottom of the mountain or from the household sites. Larger samples and repeated measures from both the household sites and mountain sites can be useful for determining whether there is a higher bacterial contamination (and statistically significant differences) at the mountain sites when compared to the house sites.

Overall, both initial hypotheses were incorrect but the results that we saw suggest that the current remediation methods need to be redirected to other potential problems. Due to the significant correlation between turbidity and iron, we suggest focusing on only one of these factors initially in future testing. Since turbidity is a physical appearance characteristic instead of a mineral deposit in the water like iron, we suggest looking further into the iron levels and correlations. Iron levels could potentially be coming from the pipes or from the environment and affecting the bacteria growth in the water. Further research is needed to address levels of iron and its influence in bacteria growth.

Table 4. Relationship Explanations of models

\begin{tabular}{|l|l|l|}
\hline Variables & Equation & Interpretation \\
\hline Iron $(\mathrm{mg} / \mathrm{L})$ v. Coliform $(\mathrm{CFU} / \mathrm{ml})$ & $($ Coliform $)=\begin{array}{c}1164.94(\text { Iron }) \\
-51.13\end{array}$ & $\begin{array}{l}\text { For one unit increase in iron, there } \\
\text { is an increase of 1164.94 CFU } \\
\text { coliform bacteria. }\end{array}$ \\
\hline
\end{tabular}




\section{- Journal of Student Research}

\begin{tabular}{|c|c|c|}
\hline $\begin{array}{l}\text { Iron }(\mathrm{mg} / \mathrm{L}) \text { v. Gram-Negative } \\
(\mathrm{CFU} / \mathrm{ml})\end{array}$ & $\begin{aligned}(\text { Gram.Neg. })= & 428.91(\text { Iron }) \\
& -44.92\end{aligned}$ & $\begin{array}{l}\text { For one unit increase in iron, there } \\
\text { is an increase of } 428.91 \mathrm{CFU} / \mathrm{ml} \\
\text { gram-negative bacteria. }\end{array}$ \\
\hline $\begin{array}{l}\text { Turbidity (FAU) v. Coliform } \\
(\mathrm{CFU} / \mathrm{ml})\end{array}$ & $\begin{array}{l}\text { (Coliform) } \\
=29.509(\text { Turbidity })+115.139\end{array}$ & $\begin{array}{l}\text { For one unit increase unit of } \\
\text { turbidity, there is an increase of } \\
29.509 \mathrm{CFU} / \mathrm{ml} \text { coliform bacteria. }\end{array}$ \\
\hline $\begin{array}{l}\text { Turbidity (FAU) v. Gram-Negative } \\
(\mathrm{CFU} / \mathrm{ml})\end{array}$ & $\begin{array}{l}(\text { Gram } . \text { Neg. }) \\
=17.143(\text { Turbidity })+11.527\end{array}$ & $\begin{array}{l}\text { For one unit of increase in } \\
\text { turbidity, there is an increase of } \\
17.143 \mathrm{CFU} / \mathrm{ml} \text { gram-negative } \\
\text { bacteria. }\end{array}$ \\
\hline Turbidity (FAU) v. Iron (mg/L) & $\begin{array}{c}(\text { Turbidity })=30.4127(\text { Iron }) \\
-2.9692\end{array}$ & $\begin{array}{l}\text { For one unit increase in iron, there } \\
\text { is an increase of } 30.4127 \text { FAU } \\
\text { turbidity. }\end{array}$ \\
\hline
\end{tabular}

\section{Conclusion}

Turbidity and iron have a positive, strong monotonic relationship with each other. Both express positive, strong, or very strong monotonic relationships with gram-negative bacteria and coliform bacteria. Looking at the slopes for each regression line, coliform is increasing faster than gram-negative bacteria when iron or turbidity is taken into consideration. That means iron has a larger impact rate in coliform than in gram-negative bacteria. Furthermore, as turbidity increases, coliform is impacted at a higher rate than gram-negative bacteria.

Samples taken from the sites and households had higher levels of certain parameters compared to EPA's recommendations for safe levels of drinking water. Iron had unacceptable levels at three locations while phosphate, coliform, gram-negative, and E.coli had unacceptable levels of each. It was stated above that more than 0 colonyforming units per milliliter (CFU/ml) was found to be harmful to humans, especially infants and the elderly. This was alarming seeing that the lowest level for E.coli was $3 \mathrm{CFU} / \mathrm{ml}$ and the highest went as high as $80 \mathrm{CFU} / \mathrm{ml}$. Coliform bacteria, on the other hand, had between $30 \mathrm{CFU} / \mathrm{ml}$ and $560 \mathrm{CFU} / \mathrm{ml}$.

Other parameters such as chlorine and nitrates had acceptable values according to EPA standards and pose little to no health hazards to the community. For example, none of our samples had over $0.02 \mathrm{mg} / \mathrm{L}$ of chlorine in them, while the CDC recommended no more than $4 \mathrm{mg} / \mathrm{L}$. Local experts such as Dr. Carrias suggest that this low level is the naturally occurring amount and shows that no water treatment is taking place (Environmental Protection Agency, 2021). Levels of nitrate in our samples were lower than recommended. This could be because the samples were collected from areas with little to no agriculture.

These baseline values compared to our collected samples showed that even in the households, the water coming from the faucets had high levels of harmful bacteria. To eliminate the coliform and gram-negative bacteria in potable drinking water the community can boil or treat the water before using it. Unfortunately, these measures are often avoided or skipped over, causing potential illnesses in the community. The mean levels of the bacteria were higher in the household collections compared to the mountain sites, counter to our first hypothesis. The village councils were working on remediation tactics that focused on cleansing the water sources, but given that our data suggests contamination does not take place from the source, those efforts need to be changed to focus resources on 


\section{- Journal of Student Research}

the households or in collection areas closer to the homes. Determining how, why, and what is causing higher levels of bacteria at the house sites is key to improving potable water in Belize.

\section{Limitations}

Time and funding limited the number of locations we were able to visit. We hope to return to Belize and the Valley Community in the future to increase our sample size and add additional sites in Billy Barquedier National Park and types of households in the surrounding community.

Another limitation that we encountered was the amount of rainfall that occurred during our sample collection period. Measuring turbidity with the HACH DR 890 Colorimeter was an important part of our experiment. Unfortunately, with our packed schedule and our limited time in the country, we were unable to collect water samples on a prolonged stay. Because of this, we had to collect the samples while it was raining which could have disturbed the turbidity of our sampling bottles. Since turbidity was measured on-site, we are unsure if this had an effect on our results but assumed that the levels were higher than normal (i.e., a sunny day where rainfall was not interfering with the transparency of the samples). It is also widely known that during the months of September and October Belize experiences heavy rainfall, whereas during the months of March and April, there is little to no precipitation. Therefore, depending on the season, turbidity levels could change significantly. It is recommended that taking water samples from households and sites during different seasons in Belize would change the parameter comparisons and collectively, a year's worth of seasonal data would provide a comprehensive understanding of contamination of water. Advisory information could then be provided for sanitation guidelines to the community throughout the year.

Lastly, upon research on E. Coli testing, we found that wait time and removal from the original environment was a larger factor than we thought. After collecting the samples, we did store them properly at the right temperature, however, we did not actually test for the E. Coli and Gram-Negative bacteria until a day later. Because of this, we risked the possibility of the E. Coli not being as prevalent when tested because it was removed from its original environment. To avoid any sort of interference, we would test the samples sooner.

\section{Acknowledgments}

We would first like to thank Mr. Josué Aké, Dr. Sherlene Enriquez-Savory, and Dr. Abel Carrias for guiding us to the sites, oversight of data collection, and further giving information surrounding Belizean culture and local water systems. Also, thank you to the five University of Belize students that accompanied us through the hike. Finally, thank you to our advisors Drs. Minerva R. Brauss and K. Daniel Brauss for providing this opportunity and to the Francis Marion University Real Grant, "Coaching, mentoring, presenting and publishing research for undergraduate students".

\section{References}

Adimalla, N. (2021). Application of the Entropy Weighted Water Quality Index (EWQI) and the Pollution Index of Groundwater (PIG) to Assess Groundwater Quality for Drinking Purposes: A Case Study in a Rural Area of Telangana State, India. Archives of Environmental Contamination and Toxicology, 80(1), 31-40. https://doi-org.fmarion.idm.oclc.org/10.1007/s00244-020-00800-4

Cabral J. P. (2010). Water microbiology. Bacterial pathogens and water. International journal of environmental research and public health, 7(10), 3657-3703. https://doi.org/10.3390/ijerph7103657 


\section{Journal of Student Research}

Centers for Disease Control and Prevention. (2020, November 17). Water Disinfection with Chlorine and Chloramine. Centers for Disease Control and Prevention. https://www.cdc.gov/healthywater/drinking/public/water disinfection.html\#: :text=What $\% 20 \mathrm{are} \% 20 \mathrm{safe} \%$ 20levels $\% 20$ of,considered $\% 20$ safe $\% 20$ in $\% 20$ drinking $\% 20$ water $\% 20$

Environmental Protection Agency. (2020, January 27). Drinking Water Regulations and Contaminants. EPA. https://www.epa.gov/sdwa/drinking-water-regulations-and-contaminants

Environmental Protection Agency. (2021, January 5). National Primary Drinking Water Regulations. EPA. https://www.epa.gov/ground-water-and-drinking-water/national-primary-drinking-water-regulations

Filip, A., Vuskovic, B., \& Strundjalic, P. (1974). Correlation Between Turbidity and Iron Content of the Filter Effluent of Well Origin. Journal (American Water Works Association), 66(3), 166-168. Retrieved May 16, 2021, from http://www.jstor.org/stable/41266992

Husaini, D. C., Enriquez, A., Arzu, T., Miranda, K., Mossiah, D., \& Cardinez, C. (2020). Nitrate Levels in Rural Drinking Water in Belize. Journal of health \& pollution, 10(27), 200904. https://doi.org/10.5696/21569614-10.27.200904

Getachew, A., Tadie, A., Chercos, D. H., \& Guadu, T. (2018). Level of Faecal Coliform Contamination of Drinking Water Sources and Its Associated Risk Factors in Rural Settings of North Gondar Zone, Ethiopia: A CrossSectional Community Based Study. Ethiopian Journal of Health Sciences, 28(2), 227-234. https://doiorg.fmarion.idm.oclc.org/10.4314/ejhs.v28i2.14

Google. (n.d.). [Marked locations of water retrieval sites]. Retrieved May 14, 2021, from https://earth.google.com/web/search/17\%2e0010,+-88\%2e42430/@17.001,$\underline{88.4243,70.21783023 \mathrm{a}, 1005.07778825 \mathrm{~d}, 35 \mathrm{y}, 0 \mathrm{~h}, 0 \mathrm{t}, 0 \mathrm{r} / \text { data=CigiJgokCXgsvwrMETFAEaSrCA9Y9zBAGd }}$ YEU5I F1bAIcshHtr2HlbA?pli=1\&hl=en

Grau, J., Navia, M., Rihm, A., Ducci, J., Martin, D., Kuratomi, T. (2013). Water and Sanitation in Belize. InterAmerican Development Bank. 14-30. Retrieved May 16, 2021, from https://publications.iadb.org/publications/english/document/Water-and-Sanitation-in-Belize.pdf

New Brunswick. (n.d.). Facts on Drinking Water: Coliform Bacteria - Total Coliforms \& E.Coli. Office of the Chief Medical Officer of Health. https://www2.gnb.ca/content/dam/gnb/Departments/hs/pdf/en/HealthyEnvironments/water/Coliforme.pdf

Water Technology. (2012, December 1). Phosphates. Water Technology. https://www.watertechonline.com/home/article/15540707/phosphates\#: :text=Regulation\%3A,0.024\%20m $\mathrm{g} \% 2 \mathrm{FL} \% 20$ for $\% 20$ reservoirs 